\title{
Malaysia's Syariah Judiciary as Global Assemblage: Islamization, Corporatization, and Other Transformations in Context
}

\author{
MICHAEL G. PELETZ \\ Anthropology, Emory University
}

\section{IN TR O DUCTION}

Scholars writing about Muslim cultures and politics in the new millennium face a number of challenges beyond those enumerated by Edward Said, Talal Asad, and their interlocutors in the late twentieth century. ${ }^{1}$ Some of them have been brought into sharp relief by geo-political realities of the post-9/11 era. This period has seen devastating U.S.-led wars in Iraq and Afghanistan, and other deeply polarizing developments in many regions of the world. These developments have entailed the emergence among Muslims and non-Muslims alike of increasingly hegemonic binary contrasts between "good Muslims" and "bad Muslims" (alternatively, "good Islam" and "bad Islam") (Mamdani 2004; AbuLughod 2005: 165-75), as, in different ways, have populist uprisings in Tunisia, Egypt, Libya, Syria, and beyond (the "Arab Spring"). They have also witnessed the advent of related dichotomies, involving, on the one hand,

Acknowledgments: I am grateful to Ikmal A. Mohd-Adil for research, editorial, and bibliographic assistance. I would also like to express my gratitude to Tuan Haji Mohamad Shakir Bin Abdul Hamid of the Malaysian Department of Syariah Judiciary (Jabatan Kehakiman Syariah Malaysia) for his interest in my research and his help in locating data relevant to the project. Thanks to David Akin, Abdullahi An-Na'im, Janice Boddy, Mark Cammack, John Comaroff, Vincent Cornell, Kim Dovey, Bruce Knauft, Robert Hefner, Jim Hoesterey, Michael Lambek, Andrew Shryock, Fatima Siddiqi, Winnifred Sullivan, Tan Beng Hui, Steve Tipton, Amanda Whiting, and anonymous reviewers for comments on earlier versions of this essay, parts of which were presented at the Association for Asian Studies Annual Meeting (2011), the Koninklijk Instituut voor Taal-, Landen Volkenkunde (KITLV; 2011), New York University (2011), the University of Victoria (2011), the Europäishe Akademie Berlin (2012), the Rockefeller Foundation's Bellagio Center (2012), and the University of Malaya (2012); the questions and comments I received in those settings helped me refine some of my arguments and were much appreciated. Recent research trips to Malaysia $(2010,2011,2012)$ were made possible by generous funding from the KITLV and the University of Malaya, where I was a visiting professor in July 2012. This essay incorporates material adapted from Peletz 2011; I alone am responsible for any errors and shortcomings.

${ }_{1}$ Many of the earlier challenges involved overcoming Orientalist legacies and the categories of description and analysis undergirding them (Said 1978; 1993; Asad 1986; 1993; Scott and Hirschkind 2006). 
"Islamophobes," an epithet for scholars, government officials, and others who out of fear, anxiety, frustration, or hatred focus on "bad Muslims" (or "bad Islam"); and, on the other, "Islamophiles," a term coined for those who purportedly train their sites on "good Muslims" (or "good Islam") or simply evince a "generalized affection for Islam and Muslims" (Shryock 2010: 9). Even progressively minded scholars who endeavor in good faith to negotiate these polarized cultural-political fields often find themselves between Scylla and Charybdis.

Related challenges that scholars of Muslim cultures and politics confront in the new millennium reflect the fact that our audiences typically suffer media and overall information saturation ("chronic fatigue") at the hands of government and corporate news media and Internet-based news sources. This challenge is not unique to scholars concentrating on the Muslim world, but is, I would argue, one that we-and those we engage in the field-experience in particularly acute terms. Another challenge, also related to our readership, has to do with the fact that many of us write for, or are held accountable by, multiple audiences: professional colleagues straddling different academic disciplines; variably situated interlocutors and friends in the field; and religious authorities and bureaucrats in the countries that host our research and sometimes vet our publications. A defensible middle ground or balance in the study of Muslim cultures and politics is exceedingly difficult to achieve. This is especially so if one seeks to produce descriptions and analyses that are robust, nuanced, empathetic, and aspire to objectivity, yet are simultaneously geared toward laying bare and critiquing structures of inequality and social processes that involve alienation or dehumanization (Knauft 1996). For these and other reasons, we should not be surprised to find that scholarly consensus bearing on contemporary Muslim cultures and politics is somewhat elusive (Soares and Osella 2009; see also Asad 1993; 2003; Scott and Hirschkind 2006).

Despite scholarly dissensus concerning many issues, there is agreement on certain broad patterns, such as the florescence since the early 1970s of Islamic piety and religiosity in conjunction with diverse manifestations of a resurgent or revitalized Islam in various public arenas. Some forms of this Islam are very much socially engaged if not strongly activist, occasionally (though not commonly) militant, and sometimes - though this is quite rare in a statistical sense when one considers the global population of 1.7 billion Muslimsviolent. The evidence thus adduced comes from most parts of the Muslim world, though scholars of comparative religion rightfully point out that we see generally similar dynamics in predominantly Christian contexts, and among Jews, Hindus, Sikhs, and Buddhists (Casanova 1994; Juergensmeyer 2003). As with capitalist markets, modern states, and civil society, it seems that public religions are here to stay. This despite their much-heralded demise in most of the twentieth-century literature bearing on modernization, 
which posited both the decline of religious beliefs and practices and their relegation to marginalized private domains as a key signifier if not the sine qua non for joining the ranks of the modern (Asad 2003).

Many scholars have conceptualized these dynamics as manifestations of processes involving the de-privatization of religion or the desecularization of public life. Others, assuming they are dealing with Muslim-majority nations in which Islamic law (syariah/shari ${ }^{6} a$ ) has gained currency, refer to the Islamization or syariahtization of legal systems, state structures, or national cultures (e.g., Hamayotsu 2002; Kepel 2002; Fealy 2005; Shaikh 2007; Liow 2009; Lee 2010). ${ }^{2}$ Academic growth-industries, think tanks, and media circuses have sprung up in the wake of these processes. I would argue, though, that in many instances both the processes and their entailments are poorly understood. This is particularly so when one ranges beyond the conventional areal foci of Islamic studies (the Middle East and North Africa) and engages data from Southeast Asian nations such as Malaysia, a religiously and ethnically diverse Muslim-majority country that in recent decades has experienced stunning economic transformation and patterns of sustained growth that are probably second to none in the Muslim world. ${ }^{3}$ The Malaysian case is of further significance in that the nation's political and religious elites enjoy a reputation in many parts of the world for representing the best of Islam and modernity, if not "the shining light of moderate Islam" (Shamsul A. B. 2001: 4709). The questions then become: How are processes of Islamization playing out in Malaysia? And what types of discourses and dynamics characterize the operations of the syariah judiciary, which is an exceedingly important player in a wide array of legal, political, and religious arenas?

I have addressed the first question elsewhere, as have others. ${ }^{4}$ Here I concentrate on the second, obviously related question. One of my arguments, based on anthropological fieldwork and archival research spanning the period 19782012, has to do with the heuristic value in the Malaysian setting of the term "Islamization," commonly utilized to gloss the heightened salience of

2 I spell Malay terms, including those of Arabic origin, in accordance with the conventions of "standard Malay," except when quoting published material following other guidelines. I should also note that I use the terms Islamic law and syariah (shari' $a$ in Arabic) interchangeably.

3 Ethnic Malays, nearly all of whom identify themselves as Sunni Muslims, constitute 51 percent of Malaysia's population of approximately twenty-nine million people (http://www.statistics.gov. my/portal/index.php?lang=en). The two other major ethnic groupings are the Chinese, the majority of whom practice a blend of Buddhism, Confucianism, and Taoism, and the Indians, most of whom self-identify as Hindus, the remainder being Muslim, Sikh, or Christian. Since all Malays are Muslims and since nearly 85 percent of Malaysia's Muslims are Malay, I use the terms Malay and Muslim (and non-Malay and non-Muslim) interchangeably when discussing ethnic, religious, and related phenomenon in the Malaysian context.

4 Peletz 1997; 2002; 2005; see also Nagata 1984; Chandra Muzaffar 1987; Muhammad Abu Bakar 1987; Hussin Mutalib 1993; Norani Othman, Puthucheary, and Kessler 2008; Liow 2009; Sloane-White 2011; Tan 2012. 
Islamic symbols, norms, discursive traditions, and attendant practices across one or more domains of lived experience. I suggest that as the term is generally used by Western social scientists and other observers since the 1970s and the 1979 Iranian Revolution in particular, it obscures an understanding of recent developments bearing on Malaysia's increasingly powerful syariah judiciary, especially those implicated in its actual workings and the directions in which it is currently moving. These latter developments, many involving bureaucratization and corporatization rather than a return to tradition, are heavily informed by common-law practices and sensibilities associated with the legal traditions inherited from British colonizers; by the rebranding of long-standing Malay practices in specifically Islamic and Arabic terms; and, more recently, by Japanese systems of management and auditing that Malaysian authorities have embraced. In order to make sense of the vicissitudes of change in the realm of Islamic law, I find it useful to regard Malaysia's syariah judiciary as a global assemblage in Aihwa Ong and Stephen Collier's (2005) sense, especially if we keep squarely in mind that it is simultaneously "a project, a terrain and target" (Cohen 1995: 39).

Brief clarification of the term "assemblage" will be helpful here. The New Oxford American Dictionary (Jewell and Abate 2001) explicates the concept with entries such as "a machine or object made of pieces fitted together" and "a work of art made by grouping found or unrelated objects." Rough analogs include a conglomeration and a miscellany. Claude Lévi-Strauss' notions of bricolage and bricoleur are both apposite, even though what he means by bricolage and what Ong, Collier, and the contributors to their edited volume mean by assemblage are very different, as are the contexts in which the terms are invoked and the objectives of their use. Bricolage is relevant because of its attention to processes and products of assembling, constructing, or creating "by means of a heterogeneous repertoire," that is, fiddling, tinkering, and, by extension, creatively utilizing "whatever is at hand," regardless of its provenance or original purpose (1966: 17); bricoleur because it emphasizes that the processes and products are the result of creative human agency involved in "doing odd jobs, repairing." Of more immediate relevance is Gilles Deleuze and Felix Guattari's (1987) work, which builds on Marx, Kafka, and Foucault, and informs both the Ong and Collier volume cited above and this essay. Deleuze and Guattari's concept of assemblage highlights "diversity, differentiation, and mobility" as well as multiplicities, metamorphoses, and anomalies (1987: 503). Unlike Lévi-Strauss' corpus, Deleuze and Guattari's is practice-oriented, drawing attention to assemblages as power-laden and "imbricated heterogenous forms" that "may open onto and ... [be] carried off by other types of assemblages" (ibid.: 509, 530-31 n. 39), and that are in any event "contested, temporal, and emergent" (Clifford 1986: 19; see also Appadurai 1996; Rabinow 1999; Marcus and Saka 2006; Sassen 2008; Anderson et al. 2012). 
To characterize Malaysia's syariah judiciary as a global assemblage is to suggest, further, that it is profitably viewed in relation to the global circulation of goods, services, discourses, and structural imperatives and constraints of various kinds, including those associated with neoliberal globalization. From this perspective, Malaysia's syariah judiciary is composed of a congeries of contested sites characterized by the interplay of a number of heavily freighted, globally inflected discourses, practices, values, and interests of disparate origins. The content of this assemblage will be empirically unpacked as I proceed. Suffice it to add here that its heterogeneities and contingencies, like its mutually contradictory transformations, are, as Collier and Ong (2005: 12) put it, the "product of multiple determinations that are not reducible to a single logic," and that in light of these dynamics I find the concept of global assemblage exceedingly useful when analyzing Malaysia's syariah judiciary.

ISLAMIZATION AND TRANSFORMATION IN THE SYARIAH JUDICIARY

\section{Islamization/Creeping Descularization}

Malaysia's Islamic resurgence, often referred to as the dakwah movement, is a multifaceted, heterogeneous phenomenon of urban, middle-class origin that dates from the early 1970 s, even though it is most appropriately viewed as an outgrowth of earlier developments in Islamic nationalism and reform, such as those associated with the Kaum Muda (Young Group) movement of the 1920s and 1930s (Roff 1967). It has been fueled by state policies in conjunction with religio-political developments elsewhere in the Muslim world; and has involved heightened expressions of piety among Malays (new technologies of the self, new patterns of comportment and consumption, including new styles of dress, new modes of greeting, etc.) in addition to other far-reaching changes. The latter include: the Islamization of Kuala Lumpur's monumental architecture; nation-wide campaigns to build and refurbish prayer houses and mosques; the passage of myriad legislative measures bearing on Islam; the creation of an international Islamic university and a nation-wide system of Islamic banking and finance; and the cooptation by the state of charismatic Muslim intellectuals by offering them influential posts in the state apparatus.

In this context it is not surprising that in recent decades Malaysian political and legal (as well as educational, familial, and other) institutions have become increasingly inflected by Islamic symbols and idioms; that the scope and jurisdiction of Islamic law have been broadened considerably; and, more generally, that what Clive Kessler (2008: 62) has referred to as "the long march toward desecularization" has proceeded largely unchecked in certain domains. Commonly cited (e.g., by Norani Othman, Puthucheary, and Kessler 2008; Whiting 2008; 2010; Liow 2009; Lee 2010) as evidence for these trends are the following six sets of mostly legal/political/religious developments, which I mention in rough chronological order. 
First, the seemingly straightforward and at first glance relatively innocuous 1988 revision of the Federal Constitution, known as amendment 121 (1A). This amendment specified that civil courts have no jurisdiction over matters falling within the purview of Islamic courts. In doing so, it largely eliminated civil-court reviews and repeals of Islamic-court rulings. It also set the stage, as far as many Malaysians and outside observers are concerned, for Islamic sensibilities and dispositions to trump the Constitution.

Second, Prime Minister Mahathir's late-September 2001 declaration that Malaysia is an Islamic state. This enigmatic declaration, which was aimed partly at offsetting President Bush's post-9/11 characterizations of Muslim polities as extremist and hostile to the United States, proved to be politically explosive in many quarters, especially non-Muslim ones.

Third, Deputy Prime Minister Najib's July 2007 public "confirmation" that Malaysia is indeed an Islamic state, which was followed by warnings from on high that those wishing to avoid detention should avoid public deliberation of whether this is in fact true.

Fourth, the apostasy case of Lina Joy (nee Azlina Jailani), which began in 1990 and culminated in a 2007 Federal Court ruling that essentially refused to recognize her renunciation of Islam - or her conversion to Christianity — on the grounds that this was a matter to be addressed by Islamic courts. The latter courts, as it happens, do not countenance apostasy involving the abjuration of Islam (though they do facilitate non-Muslims' conversion to Islam). This decision made clear that the freedom of religion enshrined in the Constitution does not pertain to those, like Joy, born Muslim.

Fifth, a host of incidents since the 1980s that have involved campaigns of Islamically inflected moral policing aimed mostly but not exclusively at Muslims, which have reached new heights in recent years. In some instances, these campaigns have been overseen by the rapidly growing and extremely well funded religious bureaucracies like JAKIM and JAWI. ${ }^{5}$ In other cases, they have been orchestrated by Islamic NGOs that aim to galvanize Muslim public opinion concerning how and in what specific directions Islamization should proceed.

And sixth, legal strategies on the part of Islamist groups to harass Muslim feminist organizations such as Sisters in Islam and other like-minded reformers, by mounting lawsuits against them alleging defamation, blasphemy, apostasy, and so forth. These strategies have become particularly intense in the past decade or so, and commonly involve what John and Jean Comaroff refer to as "lawfare." Lawfare is typically characterized by a regime's "use of its

5 JAKIM refers to the Jabatan Kemajuan Islam Malaysia (Malaysian Department of Islamic Advancement); JAWI stands for Jabatan Agama Islam Wilayah Persekutuan (Federal Territory Department of Islamic Religion). These are among the government agencies promoting Islamization (Liow 2009; Tan 2012). 
own rules - of its duly enacted penal codes, its administrative law, its states of emergency, its charters and mandates and warrants, its norms of engagementto impose a sense of order upon subordinates [and enemies] by means of violence rendered legible, legal, and legitimate by its own sovereign word" (Comaroff and Comaroff 2005: 30; see also Harding 1996: 270-74 et passim; 2012: 165-78, 248-51). In the Malaysian setting and perhaps most others, tactics of lawfare are not confined to those who are part of the state apparatus; they are commonly deployed by conservative Muslim sectors of civil society to silence groups perceived as threatening their values and interests, or those of the "race," nation, or global Muslim community (umat).

Several scholars (Norani Othman, Puthucheary, and Kessler 2008; Liow 2009) have provided superb documentation of the step-by-step constriction of public and intellectual spaces for discussing issues of public interest that these developments have entailed. Some have observed that at present the key debates among Malay political and religious elites concern not whether Malaysia is (or should become) an Islamic state, but what kind of Islamic state it already is and what types of additional measures are needed to entrench that status (see, for instance, Farish Noor cited in Fuller 2006). These observations point to a rather remarkable shift, which, to oversimplify, occurred mostly in the first decade of the new millennium. Note, for example, that as recently as 2000, the most eminent scholar of Malaysian Islamic law could write that "officially at least," Malaysia is "a secular state which has not embraced the idea of establishing an Islamic state"; "nor does it have any agenda of developing a Shari'a-based constitution” (Kamali 2000: 2).

\section{Syariah, Common Law, and the Islamic Judiciary as Global Assemblage}

It is curious that even when scholars of Malaysian Islam provide magisterial genealogies of these developments, they typically convey little sense of the dynamism of syariah or of the hierarchy of religious courts or bureaucratic behemoths, such as the Department of Islamic Judiciary (Jabatan Kehakiman Syariah Malaysia, established in 1998), charged with managing and auditing their procedures and outcomes. Except when they are addressing matters of hudud law, differences between the Shafi' $i$ legal tradition (which predominates in Malaysia) and the other schools of law in Sunni Islam, they often depict the syariah in rather static, undifferentiated, and monolithic terms, the relevant discussions chiefly confined to the expanded jurisdiction of syariah and the border skirmishes with the civil judiciary and defenders of the Constitution that such expansions commonly incite. Typically elided in these accounts are discussions of how the syariah judiciary is structured and managed; what the routine operations of the syariah courts tell us about the local cultural logics of Islamic judicial process; and how on a day-to-day basis the courts deal with male and female litigants, and matters of marriage, divorce, reconciliation, spousal maintenance, conjugal earnings, child support, and custody. 
This literature also obscures crucial dynamics that are jarringly dissonant with regard to most scholarly and popular understandings of terms such as Islamization. $^{6}$ Relevant here, and explained in more detail below, is that for many decades now the political, religious, and specifically legal elites who have been centrally involved in reforming the syariah judiciary have consciously endeavored to model it on its far more powerful and eminently more prestigious secular counterpart, Malaysia's civil judiciary, and the common-law traditions inherited from the British colonial era with which that counterpart is inextricably associated. This is not to imply that elites have abandoned efforts to enhance the operations and legitimacy of the syariah judiciary in specifically Islamic idioms. Far from it. Nor am I suggesting that all the innovations introduced in recent years, such as the formal mediation processes referred to by the Arabic-origin term sulh, which were initiated in 2001, are of non-Islamic origin or design. My point about modeling needs to be understood in relative rather than absolute, mutually exclusive terms, especially since virtually all of the world's major legal systems are deeply hybrid with respect to the historical origins of their characteristic features and the ways these features are currently configured, inflected, legitimized, and contested. Germane here is John Makdisi's (1999) argument that key elements of English common law developed by Henry II in twelfth-century England, including common-law notions of contract, debt, and trial by jury, were adapted from medieval Islamic law of the Maliki tradition practiced in North Africa and Sicily, elements of which were incorporated first into the Norman law of Sicily and subsequently into both the Norman law of England and what came to be known as English common law. Also relevant is George Makdisi's thesis that classical Islamic schools of learning (madrasah) in Palestine, Syria, Egypt, and elsewhere inspired the development and design of the earliest law schools (Inns of Court) in London, which were founded in the twelfth-thirteenth centuries and helped secure London's fame as the "'home of colleges' in the Christian West" (Makdisi 1985-1986: 15).

Circumstances of the sort outlined above and in the material presented below help explain why Malaysia's syariah judiciary is profitably viewed as a global assemblage. Put differently, the concept of global assemblage is useful both because Malaysia's syariah judiciary is a good example of a global assemblage and because the notion of a global assemblage helps us comprehend features of this judiciary that have been poorly understood or glossed over in most accounts of Malaysia's Islamization. Consider the syariah judiciary's modeling on the system of civil law. This modeling is evident in the Islamic court's greatly increased reliance on written evidence (as distinct from oral testimony) and in its heightened concern with written precedent,

\footnotetext{
${ }^{6}$ The chief exceptions are Horowitz (1994), Whiting (2008), and Maznah Mohamad (2010).
} 
reflected partly in the rapid growth in the past few decades of Malay- and English-language academic and professional publications that the nation's cadre of Islamic judges and lawyers are expected to read, master, and respect (e.g., Jurnal Hukum, Syariah Law Journal, Syariah Reports, Malaysian Journal of Syariah and Law, Shariah Journal, IIUM Law Journal). This modeling is also apparent in the Islamic courts' tendencies toward more adversarial hearings, partly a function of the recent proliferation of lawyers in the courts; and in augmented concerns on the part of court officials and lawyers alike with procedures characteristic of the civil judiciary, which were strikingly obvious both in the nearly seventy motions and hearings I observed in the syariah courts in Kuala Lumpur and Penang during the period 2010-2012 (and in the sixty or so cases in the civil courts that I sat in on for comparative purposes in 2012), and in the various legal documents shared with me during this time. I refer to procedures for lodging complaints; turning problems into cases; maintaining a sense of order and decorum in the courtroom; generating and handling summons, search and arrest warrants, affidavits, and appeals; discerning what constitutes fact, relevance, burden of proof, hearsay, and legally salient evidence; delivering and recording judgments; and for keeping records and managing paperwork and electronic files more generally. As one knowledgeable observer who studied court documents put it, the latter procedures "are borrowed wholly from common law, making them almost a carbon copy of laws used in civil (secular) courts" (Maznah Mohamad 2010: 516).

Recent decades have also seen significant shifts toward common-law sensibilities in the substance of family (and other personal status) law administered by Islamic courts, even as they witnessed controversial cases involving the imposition (in some instances commuted) of "Islamic punishments" such as whipping or caning for adultery and the consumption of alcohol. Technical examples of this shift in legal sensibilities that occurred in the late 1980s and early 1990s, and that could have easily been reversed since that time ("there is always ... a potential for relations to be otherwise" [Anderson et al. 2012: 182]), but have in fact become further entrenched, are delineated elsewhere (Horowitz 1994; Peletz 2002; n.d.), so I will not dwell on them here. Suffice it to note that several of them bear on the increasingly restricted legality of men's prerogative to enter into polygynous unions and to effect extra-judicial divorce (via the talak/repudiation clause); the more liberal division at divorce of conjugal earnings (harta sepencarian) ${ }^{7}$ and the expanded grounds for

\footnotetext{
7 Malay adat ("custom," "customary law") specifies a more "wife-friendly" distribution of "conjugal acquisitions" (harta sepencarian) following a divorce than does Islamic law. The more liberal division at divorce of conjugal acquisitions that one sees in Malaysia's Islamic courts in recent decades builds on adat, but this situation exists largely because the relevant features of adat resonate with and have been implicitly authorized by common-law sensibilities. Horowitz (1994: 566) notes that adat "has been embellished and expanded through common law adjudication and ... adoption of ... secular statute[s], whose roots are neither in adat nor Islam. The main source
} 
certain kinds of divorce initiated by women, such as fasakh (variably translated as "divorce by judicial proceedings," "judicial rescission/voiding of the marriage contract," or "annulment"). ${ }^{8}$ Importantly, such shifts have not occurred in a simple unilinear fashion; they have proceeded in fits and starts and have occasionally been temporarily or partially reversed (Kamali 2000: 12-13, 66-68, 306, 317-18; Norani Othman 2008).

Consider too that in contemporary state-sanctioned parlance, Malaysia's Islamic judges are most commonly designated by the generic (Arabic-origin) term for judge or magistrate, hakim (sometimes by the more specific hakim syarie), whose primary referent in the Malaysian context has long been civilcourt judges. The flip side is that the more conventional (Arabic-origin) term for Islamic judge, kadi (sometimes rendered qadi, qadzi, etc.), which was prevalent in Malaysia through the early 1990s and long before, is, for the most part, no longer in official use.

This socio-linguistic engineering constitutes a striking break from Islam's classical juridical past, which is inextricably linked with the term kadi, and from the terminologies and symbolics of Islamic judiciaries in most of the contemporary Muslim world. It reflects official strategies to upgrade the status and prestige of Islamic judges in relation to civil-law judges in the eyes of the legaljudicial profession and the populace as a whole. (Ahmad Hidayat Buang's [2007: 322] observation that Malaysia's "Syariah Court ... [is] seen by many as a second class, incompetent court" is clearly intended as a relative point: that the syariah court is regarded as second-class and incompetent in relation to the civil court, which in many respects constitutes the gold standard. So too is Kamali's [2000: 312] convergent, widely shared view that "The Syariah Courts and their judges and personnel ... exist on the fringes of the system and tend to see themselves as being marginalized.") Official thinking has it that such upgrades necessitate "rebranding," the term half-jokingly used by a high-ranking member of the syariah judiciary with whom I discussed these matters in 2011. A key feature of this rebranding involves capitalizing on

of the change, in other words, is the adjacent English legal system," which regulates marriage and divorce among non-Muslims and aims to accord non-Muslim women some measure of equality vis-à-vis men. See also Raihanah Abdullah, Martinez, and Wirdati Mohd. Radzi 2010.

${ }^{8}$ In some instances, appeals to common-law sensibilities are implicit or indirect, as in the 18 December 1998 letter to the prime minister signed by Sisters in Islam and other women's groups that "Muslim women of this country must also benefit from the growing sphere of rights ... accorded to their non-Muslim sisters" (cited in Kamali 2000: 119). The rights of non-Muslim women in Malaysia are governed by common law, hence the standard invoked here is clearly the latter body of law. A more recent example involved the government's 2010 announcement that two women had been appointed as Islamic judges, which was followed by a flurry of speculations concerning whether officials were going to limit their jurisdictions to cases "appropriate to female judges." In a column in a popular daily (The Star), Marina Mahathir (2010) urged authorities to refrain from imposing any such restrictions and to "let those women get on with their jobs. After all, their counterparts in the civil courts have been doing so for a long time." 
the legitimacy of the civil-court system by incorporating various features of that system into the syariah judiciary, and divesting Islamic judges of the negative connotations of the term kadi-rural, backward, capricious, and irrationalsome of which were foregrounded in Max Weber's Orientalist caricatures of "kadi-justice" (1925 [1968]). A few years ago I was in fact warned by a Malay scholar conversant with these matters that Islamic judges would be deeply insulted if I referred to them as kadi in my conversations with them. These sensibilities signaled a sharp contrast to the situation that prevailed during my fieldwork in the Islamic courts in the late 1980s, when kadi was clearly the most appropriate term of reference and address.

Corporatization and E-Governance. Thoroughly resonant with the foregoing - and with my argument that changes in the Islamic judiciary have little to do with a return to tradition - are the sartorial styles and professional activities and organizations of Islamic judges and syariah lawyers alike. Syariah lawyers (generally known as peguam syarie) are increasingly involved in hearings in Islamic courts, as might be expected in light of the rapid growth of the Malay middle class; the greater financial stakes in cases focusing on divorce, spousal maintenance, child support, and conjugal earnings (which, taken together, dominate the docket); and the pressures toward bureaucratic specialization, rationalization, and reform spawned partly by these and attendant developments. Not coincidentally, both syariah lawyers and Islamic judges organize their professional practices and formal associations on civil-law models, such as those of the Malaysian Bar Council and Lincoln's Inn. Even in small towns far from the capital, moreover, their professional attire is nowadays exceedingly "corporate" in the smartly-tailored, Western black-businesssuit sense of the term, much like (but even more corporate than) that worn by their colleagues in the civil judiciary, some of whom donned the long white wigs of their English counterparts and former colonizers through the early 1990s. Here too we see clear evidence of rebranding that capitalizes on the legitimacy of the civil judiciary.

Terms such as Islamization, like the kindred syariahtization and desecularization, obfuscate these kinds of dynamics. They sometimes suggest, or are interpreted to mean, certain kinds of homogeneous, homogenizing, or otherwise "fatefully necessary" processes (Cannell 2010: 90) that we think we understand, perhaps because of familiarity with broadly analogous processes in other parts of the Muslim world such as Iran, Pakistan, Afghanistan, or Sudan. The problem here is that if we consider the full range of developments - many of which are mutually contradictory-that have occurred in the Islamic judiciaries and national legal systems of these latter nations in recent years (Otto 2010; Hefner 2011), it is not clear whether designations such as Islamization or desecularization are particularly meaningful. These terms do, in any case, reveal very little about either the actual workings of 
Malaysia's Islamic judiciary, or, expanded jurisdictions aside — admittedly no small matter - the directions in which it is moving.

In Malaysia, the relevant dynamics have less to do with one or another variant of Islamization than with contextually variable processes of bureaucratization, rationalization, corporatization, and neoliberal globalization. In light of the scope, force, and overall salience of corporatizing developments in recent decades, I should make clear that my usage of the concept of corporatization takes as its point of departure the hierarchically authorized models, practices, sensibilities, and dispositions, along with the pecuniary and other values and interests animating and sustaining them, that prevail in upper-level management circles in corporate/capitalist business sectors of Malaysia and beyond. Especially relevant is Taylorization involving highly rationalized "assembly-line-like" processes "strictly regulated for maximum timeefficiency" and seamless mass production (Newfield 2007: 68). More generally, I am interested in the relative permeation throughout Malaysian society of certain kinds of economistic and attendant administrative/managerial principles and ideals, once associated largely with the upper echelons of rational (industrial) capitalism, that have become increasingly hegemonic and "common sensical," though variably so, across a wide variety of social, cultural-political, and other domains.

In the past two decades, Malaysian authorities, in consultation with international advisors representing a variety of fields in management and information-communication technology and a host of transnational corporations with headquarters in Western or East Asian nations, have embraced globalized forms of e-governance with a vengeance, much as Mazzarella (2006) has documented for India. Before clarifying e-governance, a fascinating example of Islamic modern Malaysian style, I should mention that these corporations include AT\&T, the Bechtel Group, British Telecom, Hewlett Packard, IBM, Intel, Motorola, Nippon Telegraph and Telephone, Peking University, and Sun Microsystems. Conspicuously absent from this list are corporate advisors representing the Muslim world.

The expression "e-governance," like the synonym "E-Government," which those who authorize official Malaysian discourse prefer, refers to the use of "high-end, state-of-the-art information and communication technologies to facilitate efficient and effective delivery of government services through ... [densely networked] electronic delivery channels." 9 Unlike earlier computerization initiatives that were essentially agency-specific, e-governance works across - and systematically integrates - the entire spectrum of state agencies. Ideally, it will enable "citizens to access, transact and obtain any government service via a range of multimedia portals such as phone, PC, mobile, kiosk

\footnotetext{
9 The passage quoted is from then-Prime Minister Mahathir's foreword to E-Government in Malaysia (Muhammad Rais Abdul Karim and Nazariah Mohd Khalid 2003).
} 
and interactive TV."10 One rationale for developing e-governance is that in order to remain transnationally competitive, and to keep ahead of the global curve, "the business of government" must be continually reinvented, building on "forms of governance" that are "at once stable and predictable yet agile and flexible." The move is also squarely embedded in ideologies of "high modernity," which James Scott (1998: 4) characterizes in terms of "a self-confidence about scientific and technical progress, the expansion of production," and "the rational design of social order commensurate with the scientific understanding of natural laws." According to the latter logic, "if the future is viewed as a scientific and technological puzzle, then E-Government will be the integral interlocking piece that completes the picture, at least for now." 12

Malaysia's commitment to e-governance is a central entailment of former Prime Minister Mahathir's Vision 2020, launched in 1991, which aimed to ensure that Malaysia would join the ranks of fully industrialized nations by the year 2020. As part of this commitment, Mahathir (r. 1981-2003) poured resources into what came to be known as the Multi-Media Super Corridor (MSC). The MSC is a zone of high-tech development 50 kilometers long and 20 kilometers wide, which extends from Kuala Lumpur's City Center in the north to the Kuala Lumpur International Airport in the south; it contains Putrajaya, the government's administrative capital, and offices for over forty thousand federal employees, ${ }^{13}$ as well as Cyberjaya, a massive IT-themed town, spread across 7,000 acres, with a science park and university complexes at its core. Sometimes characterized as a mélange of Silicon Valley and Hollywood, the MSC is a key component of the government's strategy to create "a technology-literate workforce that can perform in a global environment and use Information Age tools to support a knowledge-based economy."14 E-governance, for its part, is promoted in official publications as "the crown jewel of the MSC," though one should add that, according to some scholars (Bunnell 2004), the MSC has fallen far short of government expectations.

E-Syariah Portal. In 2002, as part of the e-governance initiative, authorities rolled out an extremely sophisticated, visually stunning, and highly interactive E-Syariah Portal. The E-Syariah Portal was created with a number of specific goals in mind (in addition to the general objectives of e-governance noted earlier). One is to enable Islamic judges, lawyers, state auditors, and others to code, classify, manage, and track cases and their outcomes electronically, thereby reducing the notorious backlog of suits along with widespread

${ }^{10}$ Muhammad Rais Abdul Karim and Nazariah Mohd Khalid (2003), 54-55.

11 Ibid., 2.

12 Ibid., 3 .

13 Ibid., 85 .

14 Ibid., 32. 
criticisms along the lines of "justice delayed is justice denied," which highlight the plight of women, who continue to comprise the vast majority of plaintiffs in the Islamic courts. ${ }^{15}$ Another objective of the E-Syariah Portal is to facilitate officials' efforts to amass reliable information on the whereabouts and financial resources of litigants and other "persons of interest" to the Islamic judiciary and to the police, the military, and others who help them develop their databases.

The E-Syariah Portal is also designed to disseminate legal forms and other relevant information to litigants and others, who are collectively and interchangeably designated in official literature as "users," "customers," "citizen-users," and "change targets." Users can surf the sites accessible through the E-Syariah Portal to obtain information both on syariah lawyers who are registered with the system, and on any of the 140 or so different types of civil and criminal cases handled by the Islamic judiciary. Users can also access information relevant to the state-specific statutory laws that bear on each type of case. For many of them, moreover, users can activate live links to passages from the Quran and hadith that officials have selected to provide authoritative religious rationales for the statutory laws and relevant punishments in question. In addition, the portal prominently displays the exact times at which Muslims are called to prayer each day. The portal's myriad live links also enable users to access the various web-pages created by the Department of Islamic Judiciary, which include (inter alia) an extensive glossary of more than seventy terms relevant to the Islamic courts, many of which are borrowed from the largely English (or English-derived) lexicon of the civil judiciary; for example, affidavit, bailiff, injunksi, klient, kontrak, litigan, saman. One of the reigning ideas is that the portal will serve modern Muslims' needs in much the same way as a "one-stop shopping center."

The E-Syariah Portal is thus equipped with critically important pedagogical, legitimating, and regulating tools. These tools are geared, on the one hand, toward encouraging technological and digital literacy, much like the courts encouraged print-based literacy during my fieldwork in the late 1980s, and, on the other, toward enhancing surveillance, discipline, and control. Not surprisingly, the latter goals are omitted from official pronouncements, which are cast in discourses of reform that "promise and pledge" to "revise and streamline Islamic law" and its administration, to clarify the "visions, missions, and (quality) objectives" of the courts, and to "manage complaints and advice within 14 days of their receipt." According to spokesmen in the Prime Minister's Department, the more encompassing E-Syariah Project aims to "introduc[e]

\footnotetext{
15 Amidst the many currents of change described here, a key constant is that the vast majority of plaintiffs are women and that most defendants are men, typically plaintiffs' husbands or former husbands, who are summoned to court either to address charges of failure to provide spousal maintenance or child support, or to clarify plaintiffs' marital status (e.g., whether they have formally divorced their wives or have simply abandoned them or been negligent in sending them money and news of their whereabouts).
} 
administrative reforms to upgrade the quality of services of the Syariah Courts by enhancing the effectiveness of the Islamic Justice Department ... in coordinating and monitoring its respective agencies and to improve the productivity and efficiency of the Syariah Courts management nationwide" (Muhammad Rais Abdul Karim and Nazariah Mohd Khalid 2003: 78-79). Rather hard to miss is the global management-speak suffusing these kinds of official overviews; the point that one objective of such initiatives is to "upgrade and enhance the efficiency and effectiveness of the government's administrative machinery" as a whole; ${ }^{16}$ and the fact, quite familiar to most readers in these neoliberal times, that "good governance is ... [made] synonymous with sound development management" (Rittich 2001: 932, cited in Sassen 2008: 201; see also Mazzarella 2006). ${ }^{17}$

Japanese Management and Auditing. More recently, we see evidence of an extension or revival of Mahathir's Look East policy of the early 1980s, which included government and corporate efforts to utilize Japanese management techniques in local industrial production in order to encourage continued Japanese investment and inculcate Malay employees with a version of the Japanese work ethic. I refer to the fact that the syariah judiciary and the governmental apparatus in its entirety have adopted Japanese systems of corporate management and financial auditing. This has involved launching widely advertised campaigns that emphasize the 5Ses - in Japanese: Seiri, Seiton, Seiso, Seiketsu, and Shitsuke; in Malay: Sisih, Susun, Sapu, Seragam, and Sentiasa Amal; in English: Sort, Set in Order, Shine, Standardize, and Sustain. These euphemistic glosses do not do justice to the goals or demands of the campaign. Suffice it to say that such campaigns aim to encourage new modalities of self-management, ethical engagement, and "social awareness" (of one's self, one's work habits, one's coworkers, one's workplace) so as to better discipline, motivate, and govern Muslim and other Malaysian citizen-subjects; enhance their efficiency, productivity, personal accountability, and global competitiveness; and help guide them - and the nation - to a more prosperous and secure future (see Rudnyckyj 2010).

When I visited the Islamic court in Kuala Lumpur in the (northern) summers of 2010 and 2011, the campaign was in full swing. The walls of the registrar's office, for example, were not only adorned with the usual photographs of the Prime Minister, the King, and the Queen, plaques bearing beautiful calligraphic renderings of the words Allah and Muhammad, and flow charts depicting the organization of the court hierarchy and the stages involved in processing cases. They also featured prominent wall hangings celebrating and

16 Tan Sri Samsudin Osman (cited in ibid., front matter; my emphasis).

17 The tallies of "hits" posted on the webpages of the E-Syariah Portal and the sites to which they are linked indicate that these websites are widely visited by the public. But I know of no reliable data indicating how dependable they are, for example, when potential litigants endeavor to use them to download forms. Anecdotal evidence suggests that they are often inoperable. 
explicating the new, Japanese-origin system of management and auditing, some of which enumerated the 5Ses in both Japanese (a language that is unintelligible to virtually all Malays and other Malaysians) and Malay. In their backstage offices, moreover, various members of the judiciary were wearing jackets emblazoned with the $5 \mathrm{~S}$ logo. Others thumbed through, carried around, or had within easy reach official guidebooks for implementing the 5Ses, such as Panduan Amalan 5S Sektor Awam (5S practice guide[book] for the civil service [Government of Malaysia 2010]); these include glossy color photographs illustrating the proper way to maintain one's bulletin boards, filing cabinets, surge protectors, and toilets. The more expansive goal is to ascertain how best to manage and audit the workflow, overall operations, and "outcomes" of the syariah judiciary and otherwise provide the public with the quality and type of service demanded by Total Quality Management (TQM) protocols and the International Organization for Standardization (ISO). The ISO is, for a great many Malaysian policy-makers, the ultimate arbiter with regard to an everproliferating range of standards and more encompassing normativities for business, government, society, and culture alike, as is readily apparent to anyone who has recently spent time in Malaysian universities, government offices, bookstores, or other venues associated with the production or dissemination of official or public culture.

This last, Japanese-inflected corporatizing development dates from 2010. Systematic assessment of its full impact might thus be premature. It is quite likely, however, that it will affect employee productivity and morale, courtroom procedures, and dealings with the public in some of the same general ways as the studies collected in Marilyn Strathern's edited book Audit Cultures (2000) describe for broadly analogous dynamics in the United Kingdom, Greece, New Zealand, and elsewhere. One set of common themes underlying the differences in these cases is that they typically involve "coercive accountability" on the part of those subject to rapidly proliferating audit regimes. Limited resources (time, money, intellectual capital) associated with the provisioning of vital services are subject to compulsory reallocation so as to meet one-size-fits-all assessment protocols based on top-down corporate business models that are patently ill-suited to many of the extra-business contexts in which they are unilaterally imposed. Another common theme is the diffuse, enduring alienation experienced by employees who feel their relative autonomy and authority to make informed judgments about the workplace and the services they provide have been seriously compromised by bottom-line corporate considerations masked in discourses focusing on efficient time-space management or lofty ethical imperatives.

This is precisely what we see in Malaysia's civil courts: the fetishization of key performance indicators (KPIs) has become a tyranny for judges and lawyers alike, litigants (especially plaintiffs) being the most disadvantaged (Whiting 2011). Should we see similar developments on the Islamic 
side - and one syariah judge told me emphatically that they are already evident in the syariah lower courts - the major losers could well be women, who, unlike men, are heavily dependent on the courts, and hence the state, to negotiate their relationships with their spouses.

Even if systematic assessments of the effects of runaway audit culture in the syariah judiciary are premature, the other dynamics alluded to here have been evident for decades now and merit serious consideration. Some of them raise intriguing, politically sensitive questions about the ontological status of present-day Malaysian syariah. One question has to do with the bureaucratized, corporatized, positivized syariah that is practiced and experienced in contemporary Malaysia: Does this form of syariah have any organic or other connection with the pre- and early modern variants of syariah that, in addition to being community-based, were thoroughly grounded in local cultural conventions and certain kinds of "ijtihadic hermeneutics," as scholars like Wael Hallaq (2009), addressing the Muslim world as a whole, have discussed with such insight and clarity? The question is an exceedingly important one in Malaysia and elsewhere in light of heavily freighted debates and wars of position bearing on what is authentically (or quintessentially) "Islamic," what roles one or another conceptualization of syariah should play in the nation at present and in the years to come, and who is qualified to engage these debates.

Ijtihad, Sulh, and Nusyuz. The ijtihadic hermeneutics Hallaq has written about were predicated partly on two assumptions running throughout Islamic jurisprudence: First, "each individual and circumstance was ... unique, requiring ijtihad [independent reasoning/judgment; innovative legal interpretation of (or on the basis of) sacred texts; judicial creativity $]^{18}$ that was context-specific" (ibid.: 546). Second, this reasoning/judgment should therefore typically take into consideration a relatively expansive range of disputants' actions, intentions, character traits, and biographical data. These assumptions diverge rather sharply from those informing common-law reasoning and the notion of binding precedent in particular, for example that individuals are, put somewhat facetiously, "indistinguishable members of a generic species, standing in perfect parity before a blind lady of justice" (ibid.: 546), such that a decision rendered in one instance might be more or less automatically invoked-and potentially binding - in any "like case." Hallaq contends that legal hermeneutics based on ijtihad constitute one of the defining features of classical variants

18 Countless scholarly tomes have been devoted to the meanings of the term ijtihad. The English glosses I have provided in the text, which derive from Hallaq (2009) and other sources, convey some of the more basic senses of the term. For incisive commentary on ijtihad's general meanings and some of its more technical features, see Hallaq (2009) and the references cited in his bibliography. An important caveat to register here is that the ensuing argument I make about the exercise of ijtihad on the part of sulh officers is based on a broad rendering of the notion of ijtihad and would be problematic if I took as my point of departure some of the more technical meanings of the term. 
of syariah as well as the feature of syariah that was most adversely affected by its encounter with the political, legal, and epistemological regimes of colonialism, post-colonial states, and modern states generally. The latter assertion is most relevant here, and receives a good deal of support from developments in Malaysia (which Hallaq cites frequently) and most other Muslim-majority nations. For reasons such as these, Hallaq speaks of the "epistemic breakdown" and "desiccation and final dismantling" of syariah in the modern Muslim world; alternatively, of its "structural death" (ibid.: 15, 535, 547).

As a friendly amendment to these arguments, I would underscore that while they seem quite relevant in light of data on judicial processes overseen by Islamic judges in many Muslim-majority settings, they might merit qualification if we shift our focus to the mediation cum counseling sessions orchestrated by those currently referred to in contexts like Malaysia as "sulh officers" (pegawai sulh). (Sulh, as explained below, is an Arabic-origin term denoting the end of quarreling with the intention of compromise.) I say "might" because unlike regular hearings in Islamic courts, which are open to the public, these sessions are designed and guaranteed to be highly confidential and are thus inaccessible to local and foreign researchers who might want to observe them first-hand, and because, to mix metaphors, the jury is still out on this matter.

Before elaborating on my argument that the sulh process may be the best place in Malaysia to look for evidence of ijtihadic (or ijtihad-like) hermeneutics, a bit of background is in order. The sulh process was formally introduced in Kuala Lumpur as a pilot project in 2001 (though it has been practiced informally there since 1976) and spread to various states in the following years. The formal appointment of sulh officers followed experiments (in courts, schools, and workplaces) that were variously informed by U.S.-style psychological and social work counseling and the alternative dispute resolution movement that gained traction in North America and beyond beginning in the 1970s. The goal of these experiments was to reduce the backlog of suits that have long plagued the nation's Islamic courts and to help resolve disputes amicably. According to one source published in 2008, "since ... [its] introduction ... in 2001, 70\% of cases have been resolved" via sulh (cited in Ramizah Wan Muhammad 2008: 43; see also Sa'odah binti Ahmad 2010: ch. 5). I would submit, though, that the question of "resolution" is more complicated than suggested by this seemingly straightforward assertion. One reason for this has to do with the previously noted fact that the vast majority of suits are brought by married or formerly married women; more specifically, "resolution" often means that court officials have successfully encouraged female plaintiffs, who tend to be modestly educated and poor, to drop charges and petitions against recalcitrant husbands or ex-husbands, and/or to endure marital and domestic dynamics that are untenable. Another is that more or less mandatory counseling/mediation sessions often deter women (and men) from seeking out the courts' services in the first place. Critically important circumstances such as 
these are nowhere evident in official ledgers that purportedly offer clear, uncontested numerical assessments of key performance indicators or other grist for auditors' mills.

Sulh officers are expected and encouraged to exercise considerable freedom and creativity in eliciting their clients' sentiments and dispositions regarding the issues that have brought them to court. As one scholar explains, "It is the duty of the Sulh officer to use his or her soft skills to stimulate the conversation and to generate ideas so that the parties can discuss the matter freely" (Ramizah Wan Muhammad 2008: 46). In creatively using their "soft skills" to encourage wide-ranging conversations including the relatively no-holds-barred airing of grievances, sulh officers are much like the assistant kadi I observed in the district of Rembau, Negeri Sembilan on a regular basis during the period 1987-1988 (Peletz 2002: chs. 2-4; see also Sharifah Zaleha Syed Hassan and Cederroth 1997). The assistant kadi was also known as the "women's official" (pegawai wanita; the forerunner of today's sulh officer) because it was her job to provide morally corrective advice (nasihat) to the mostly female plaintiffs and help them manage their disputes, ideally within the context of marriage rather than through its dissolution, and thus to insure that litigants and potential litigants alike did not require the services of the kadi.

Sulh officers are noticeably less constrained in these arenas than are judges; conversely, they are in a much better structural position to exercise ijtihad, even though, in contrast to judges, they do not enjoy powers of formal adjudication, which some in Malaysia and elsewhere see as a sine qua non for the practice of ijtihad. Partly because of the expanded presence in the courts of lawyers (who, like judges, are schooled both in common law and in syariah, fiqh, and related subjects), judges must be more attuned to officially sanctioned procedure and protocol, and the "relevant facts" at issue, all of which are increasingly narrowly defined by formally gazetted enactments that regulate all varieties of substantive and procedural matters. That said, sulh officers must also adhere to a mind-numbing array of bureaucratic dicta and guidelines (Sa'odah binti Ahmad 2010: 173-74). So the point about ijtihad is ultimately a relative one that is confessedly somewhat speculative. It merits more research, based ideally on the kind of "deep hanging out" (Geertz 2000) that has long been the defining feature of the ethnographic enterprise, though, again, sulh sessions are currently off-limits to both local and foreign observers.

That the ranks of sulh officers are far more likely than those of judges to include women is a matter of great import to many members and observers of the syariah judiciary, and to litigants and potential litigants alike, though often for very different reasons. As of August 2012, women comprise slightly more than half [48/91]) of Malaysia's sulh officers, but a mere 2.7 percent (4/148) of the nation's syariah judges. It was only in mid-2010 that the government agreed to appoint women as judges in the syariah judiciary. This long-overdue move 
was intended as a sign from authorities that the stewards of Malaysian Islam seek to continue to develop Islamic institutions that are both moderate and progressive.

Considering all that is at stake - and how variegated are the legal, administrative, management, and attendant discourses and practices that authorities have drawn upon in rationalizing the Islamic judiciary-it should come as no surprise that much energy has been invested in attempting to legitimize the sulh process in cyberspace and through other advertising campaigns that underscore its Arabic and Islamic origins. Interestingly, sulh is commonly referred to as "mediation" in brochures available from the Islamic courts and on official websites of the syariah judiciary. The English terminology is frequently used in the relevant Malay-language texts, partly because many urban Malays are familiar with its general meanings as well as its specific uses in civil-court arenas, but are altogether unfamiliar with the Arabic-origin term sulh, which authorities are endeavoring to popularize, largely against the grain.

In Malaysia, the general processes involved in sulh, along with the valorization - both in the courts and other contexts - of mutual accommodation, compromise, and mediation, are in fact of great antiquity. There is nonetheless much that is new here: (1) the formalization and bureaucratization of these processes in the Islamic courts, including policies rendering them more or less mandatory for those who seek to have certain aspects of marriage/divorce cases heard by an Islamic judge (unless they prefer a trial); (2) their rebranding in specifically Arabic and Islamic idioms, even as sulh officers are encouraged to obtain training and certification from Australian mediation consultancy firms and to qualify for membership in the United Kingdom Chartered Institute of Arbitrators; and (3) efforts on the part of the syariah judiciary to signal that in addition to being grounded in the Quran and hadith, they are compatible with the common-law practices of civil courts. Conspicuously absent from these discourses are references to the traditional Malay precedents for sulh. This absence is in keeping with the current thrust of the hyper-rationalist social engineering central to Malaysia's modernity projects, which are more concerned to create modern Muslims than modern Malays, though the distinction between the two is often elided and the signifier Muslim is often a codeword for Malay and vice versa, as is also true for the designations religion and race.

The glossy brochure on sulh distributed by the syariah judiciary illustrates the diverse kinds of legitimacy work authorities are undertaking to smooth the implementation of the sulh process and establish its authenticity to a number of different, mostly Muslim constituencies. The initial section of the brochure, under the heading of "understanding sulh" (pengertian sulh), grounds the practice in moral and specifically Islamic terms. It does this by clarifying, in the very first sentence of the text, that Al-Sulh is an Arabic word denoting the end of quarrelling/disputing (putus pertengkaran) with the intention of 
compromise, adding that it involves an agreement among Muslim parties to end conflict. The brochure goes on to note that in civil law sulh is known as "mediation," using the English expression in this context. This implicitly legitimizes the practice in common-law traditions as well, simultaneously effecting the kind of double legitimization that one sees in many domains of the syariah judiciary. That the overall thrust of this legitimization is in Islamic discourse is evident by the relatively lengthy section that follows, titled "Al-Sulh from the perspective of Islamic law," which clarifies sulh from the vantage point of the Quran and hadith. This section includes a passage from Surah an-Nisa (verse 128) of the Quran emphasizing, "If a woman fears ill-treatment [nusyuz] or disregard by her husband, it shall be no offense to them to arrange an amicable settlement, for peace/conciliation is best." Next is a reference indicating the necessity for Muslims to seek peace or compromise, followed by a hadith, also exhorting peaceful resolution of differences, especially between husbands and wives.

The invocation of the heavily freighted moral and legal concept of nusyuz, which is commonly rendered into English as spousal-or, more narrowly, wifely-disobedience or recalcitrance (or failure to honor the marriage contract), is revealing if somewhat misleading. For while the Quran specifies that nusyuz may occur at the hands of either husbands or wives, Islamic law in present-day Malaysia makes no provision for nusyuz by husbands, defining it as an offense that only wives may be guilty of. Findings of guilt with respect to nusyuz can abrogate a wife's claims for material support and can thus be devastating, materially and otherwise.

Developments bearing on nusyuz in the past few decades are quite telling. According to some published sources, certain legislators and members of the Islamic judiciary have interpreted 1994 amendments to the 1984 Islamic Family Law Act to affirm that "a wife's attempt to avail herself of divorce by ta'liq based on the husband's breach of a stipulation in the marriage contract amount[s] to disobedience (nusyuz)" (Norani Othman 2008: 39; Nik Noriani Nik Badli Shah 2008: 187-90). At this juncture, judicial and other interpretations along these general lines, to the effect that women who approach the court seeking divorce are guilty of nusyuz, do not appear to be widespread. Aggregate data from the Department of Islamic Judiciary for the period 2005-2010, though extremely rich in many respects, are not particularly helpful here, for under the heading of nusyuz they list only suits involving charges of nusyuz that are filed by husbands as plaintiffs. Statistically speaking, such suits are exceedingly rare. ${ }^{19}$ Far more common are charges of nusyuz on the part of husbands who, as defendants, seek to undermine their wives' claims

19 During the period 1 January 2005-31 December 2010, there were some ninety-two thousand new civil cases in the syariah courts involving male petitioners/plaintiffs, but only 501 of them centered on charges of nusyuz. 
against them by insisting that the reason they have not properly maintained their wives is because the latter are guilty of nusyuz and thus not morally or legally entitled to support. Unfortunately, however, these kinds of counterclaims do not show up in the aggregate data either. Islamic judges and others I spoke with in 2011 and 2012 indicate that counterclaims of this variety are highly unusual in rural settings but increasingly frequent, indeed, "very common," in urban contexts such as Kuala Lumpur (though they are usually unsuccessful, due to lack of evidence). One reason for this is the greater stakes in urban divorces, many of which involve members of the new middle classes, who have far more to win or lose than do their rural/agrarian counterparts. There is a related but more compelling factor, also underscored in interviews with members of the syariah judiciary: urban (unlike rural) divorce cases usually involve lawyers, and lawyers typically advise husbands that one way to vitiate their wives' petitions against them - and to dissuade their wives from dragging them to court in the first place- is to charge them with nusyuz, or threaten to do so.

More generally, syariah court decisions published in Jurnal Hukum, Malayan Law Journal, and other relevant repositories consulted by observers and practitioners of Islamic law, along with anecdotal evidence from media exposés and other sources, indicate that men are ever more inclined to level charges of nusyuz against wives whose material claims they seek to undercut - even when their wives have not engaged in behavior that might be construed as nusyuz. Developments such as these might be expected since the past few decades have seen greatly expanded consciousness of and engagement with Islamic law and normativity on the part of Muslim men and women alike. Put differently, as Muslims in Malaysia and elsewhere gain more familiarity with syariah and the workings of Islamic judiciaries - from sulh sessions, cyber-space, and other sources bearing on Islamic law-they will increasingly use all the discursive resources at their disposal both to get justice and to get even. ${ }^{20}$ Of broader concern in light of the central arguments of this essay is that the heightened prevalence of sulh and (alleged) nusyuz, both of which have deep roots in classical Islamic jurisprudence, is an entailment of bureaucratic rationalization and attendant features of Malaysian modernity-rather than a return to tradition - in a Muslim-majority nation in which elites and ordinary folks alike commonly invoke symbols and idioms of Islam to legitimize and/or come to terms with many different kinds of change.

CONCLUSION: SOME COMPARATIVE AND THEORETICAL IMPLICATIONS

My main goals in this essay have been threefold: to delineate some of the empirical complexities of Malaysia's syariah judiciary and the mutually

20 The phrasing here owes much to Merry (1990). 
contradictory directions in which it is moving; to problematize the trope of Islamization as a gloss for these phenomena; and to illustrate that this judiciary is profitably viewed as a global assemblage. In these concluding remarks, which focus largely on Islamization, I draw attention to broader issues, including some of the advantages and limitations of the notion of assemblage.

There are important comparative and theoretical implications of my argument that the term Islamization is a woefully incomplete and otherwise misleading gloss - partly because it is so reductionist - for the changes that have occurred in recent decades in regard to Malaysia's syariah judiciary. Processes of Islamization and syariahtization, like those involved in desecularization, and of course secularization, are not monolithic, seamless, or all encompassing, like a steadily advancing prairie (or forest) fire or some giant avalanche or tsunami. Their directions, dynamics (in terms of force, intensity, degree of institutionalization, etc.), and overall vicissitudes vary tremendously across the terrain of any particular case and, needless to say, from one case to the next (Agrama 2010b; Starrett 2010). Their temporally specific, always emergent, and invariably contested "products," moreover, commonly involve a "reorganization of functions and a regrouping of forces" (Deleuze and Guattari 1987: 320). They are thus usefully viewed as global assemblages insofar as they are forged in relationship with a multiplicity of global discourses, practices, incentives, and constraints, widely disparate in origin, often keyed to analytically distinct processes of bureaucratization, rationalization, and corporatization.

Our descriptions and analyses need to make provision for the variegated nature and provenance of these discourses and practices, their ever-shifting articulations in rapidly changing fields of forces, and the different ways in which legal, religious, and other "orders [take shape and] endure across differences and amid transformations" as well as "how orders change and are reworked" (Anderson et al. 2012: 173). If they do so, they can help clarify a number of empirical and conceptual issues, including: (1) Why, across time and space, the operations and directionalities of global assemblages are "heterogeneous, contingent, unstable, partial, and situated" (Collier and Ong 2005: 12), though of course variably so; (2) Why they cannot be reduced to a single cultural-political or other logic of the sort often foregrounded or assumed by designations such as Islamization, syariahtization, and desecularization; and related to this point, (3) Why terms of the latter variety have often been invoked to explain changes in Malaysia's syariah judiciary even as arguments of a rather different if not contradictory sort, involving claims that recent years have seen "the [common-law] legalization of Islam" rather than "the Islamization of [common] law" (Horowitz 1994: 257), ${ }^{21}$ the development of

\footnotetext{
21 The passages from Horowitz pertain to legal developments in Malaya during the colonial era, but they are in keeping with his overall argument about late-twentieth-century developments in Malaysian law.
} 
Malaysian "Anglo-Shariah law" (Hooker 1999: 75), or the "secularization of [Malaysian] sharia" (Maznah Mohamad 2010), have simultaneously been advanced to sum up transformations in the same assemblage.

To put some of this more broadly: legal (and other) assemblages have their own unique logics and enjoy a (variable) measure of autonomy or "semiautonomy," in Sally Falk Moore's (1978) terminology, even when they operate in states characterized by exceedingly top-heavy executive branches that resort to lawfare to manage and control their agendas, personnel, and other resources. This is true whether or not the assemblages are implicated (as they are in Malaysia) in the shrinking space between syariah and civil-law arenas and in related processes that have seen many features of the civil judiciary folded into the realm of syariah, resulting in an increasing amalgamation of the two domains favoring the heightened salience of organized Islam in the public sphere. Expressed as a negative proposition, changes in legal assemblages, including those that are heavily inflected by politics and religion, are not appropriately construed as epiphenomena either of dynamics in political domains, where (in Malaysia and most other Muslim-majority nations) processes of Islamization are deeply entrenched, or of heightened piety or religiosity in private or public realms, another hallmark of Islamization in much of the Muslim world.

This is not the place to provide a genealogy of the term "Islamization," a floating, open-ended signifier with "meanings fluid, variant, and elusive" (Starrett 2010: 628) that has long been used by Muslim intellectuals to conceptualize various processes in early and subsequent Islamic history (Al-Attas 1969; Ali 2010). My interest in the term focuses on its invocation since the 1970s by Western social scientists and other observers concerned with the late-twentieth-century resurgence or revitalization of Islam and the main-

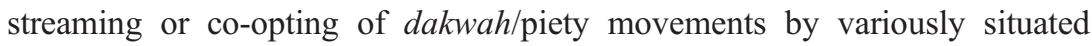
state forces and agents of governmentality. During this time Islamization has become a "gate-keeping" concept in Arjun Appadurai's (1986) sense. Such concepts (e.g., fundamentalism, political Islam, Islamism) "define the quintessential and dominant questions of interest in the region" (ibid.: 357). In doing so, however, they sometimes "limit anthropological [and other] theorizing about the place in question" (ibid.) - in this instance, the Muslim world in its entirety. Similar gate-keeping has occurred with many valuable anthropological studies focusing on topic-locale icons such as "lineage in Africa, exchange in Melanesia, [and] caste in India" (Fardon 1990: 26). Like these and other concepts (totemism, kinship) used with reference to societies broadly distributed across space and time, the notion of Islamization often discourages recognition of the complexity of the phenomena to which it is purportedly relevant (social, cultural, and political change among contemporary Muslims). Recent developments in Tunisia, Egypt, Libya, and Syria - to say nothing of post-9/11 dynamics in Iraq and Afghanistan - make it clear that we do not get very far 
by shoehorning our observations and analyses into problematic binaries such as secularization versus desecularization/Islamization (alternatively, "good Muslims" vs. "bad Muslims," or "good Islam" vs. "bad Islam”).

Many transformations presently taking place in the Muslim world have little if anything to do with Islam per se, though some obviously do. That social, political, and other changes involve Muslims does not automatically render them good candidates for inclusion under the rubric of Islamization, unless of course one makes the untenable two-fold claim that Muslims are necessarily "more religious" than Christians, Jews, Hindus, Buddhists, and others, and that, following from this, virtually everything Muslims do, say, think, or feel is ultimately motivated by or otherwise keyed to a feature of Islam. In the absence of hard data supporting these kinds of claims, we are best advised to proceed empirically, on a case-by-case basis, with the aim of generating fine-tuned ethnography and the kinds of richly comparative sociohistorical and analytic insights for which Weber, despite his problematic depictions of "kadi-justice" and other "essences" of Islam, is justly famous.

In their recent review of anthropological studies of Islam and politics, Soares and Osella (2009: 2) caution against "automatically privileging religion as the principal — or perhaps unique - foundation for Muslim identity and political practice." They encourage a focus on islam mondain, "which could be translated as "Islam in the present world" (11) and the development of a more nuanced, ethnographically grounded appreciation of the many different ways of being Muslim. "Islam mondain does not privilege Islam over anything else, emphasizing instead the actual worlds in which Muslims find themselves. This allows us to avoid, on the one hand, narrowly instrumentalist analyses of the relation between Islam and politics, and, on the other, analyses that reduce the politics of Muslims to an epiphenomenon of Islam or the micro-politics of ethical self-fashioning" (ibid.: 12).

Broadly similar approaches, according priority to the everyday lives and quotidian religious and other practices of "ordinary Muslims," have gained currency in recent years, as have related, practice-oriented or "praxiological" perspectives on Islamic law in highly centralized judiciaries (Messick 1993; Peletz 1997; 2002; Bowen 2003; Ahmad and Reifeld 2004; Marsden 2005; Agrama 2010a). Sociologist Baudouin Dupret's study of Islamic law in Egypt is relevant here, partly because his observations are germane to Malaysia, Indonesia, and many other Muslim-majority contexts. Dupret observes that when Egyptian judges deal with cases involving Islamic law, 'Explicitly 'Islamic' considerations are few" (2007: 97), despite the Islamization of many features of Egyptian politics and everyday life. Arguing that scholars of Islamic law need to focus "much more on living phenomena and actual practices," Dupret underscores "the overwhelmingly routine character ... of professional practices which are oriented to nothing but the accomplishment of the law" (ibid.: 83, 85). Dupret's other points are worth quoting at length. 
At the very place where it is supposed to be massive and overwhelming, that is, in personal status law, references to Islamic law are conspicuous for their paucity. This suggests that the issue of Islamic law in contemporary Egyptian law does not proceed from what the scholarly tradition generally claims. Reference to Islam is occasional; moreover, it is always mediated through the use of Egyptian law's primary sources, that is, legislation and case-law.... [T]his reference takes place in the banality and the routine of a judge's activity, which consists mainly in legally characterizing the facts submitted to him.... [T] he judge is ... more interested in manifesting his ability to judge correctly - according to the standards of his profession, the formal constraints that apply to its exercise, the legal sources on which he relies and the norms of the interpretive work his activity supposes - than he is to reiterate the Islamic primacy of the law he implements. There is no doubt that, if asked, the same judge would underscore the conformity of his activity and the law he applies with Islamic law. However, such an attitude would only be retrospective, a posteriori and justificatory. In the course of his work, the judge does not orient himself to the necessity to assess the Islamic dimension of any object, even in this domain of law where the Islamic genealogy of rules seems most evident.... [L] aw is a practical accomplishment, rather than an archaeological search for the Islamic pedigree of the norm" (2007: 97-98).

Approaches like these reveal that in dealing with Islamic law, the everyday discourses and operations of courts in Egypt are not too dissimilar from their Malaysian and Indonesian counterparts, and that, certain obvious differences aside, all such courts have a good deal in common with lower courts in the United States as described by Merry (1990). These kinds of approaches thus go a long way toward de-exoticizing syariah and the varied assemblages in which it operates.

I (re)turn finally to the notion of global assemblage, which I view as "good to think with" and more useful as a heuristic device for understanding dynamics of change in Malaysia's syariah judiciary than the trope of Islamization or any others that come to mind. I mentioned earlier that the concept of global assemblage is valuable both because the syariah judiciary is a good example of a global assemblage and because the concept of global assemblage helps us comprehend features of the syariah judiciary that have been poorly understood or elided in most accounts of Malaysia's Islamization and modernity. Here I want to underscore a different, cautionary point. If scholars have at times been too quick to see evidence of Islamization amidst the transformations presently occurring in the Muslim world, there are analogous dangers in usages of terms like assemblage that are overly facile or literal. The concept of assemblage has been utilized by anthropologists (and others) since the late 1990s in lieu of notions such as system and structure, which undergirded a good deal of descriptive and analytic work in the social sciences and humanities through the mid-to-late twentieth century and were often intended, or taken, to imply degrees of fixity, coherence, stability, and finality. I would caution that we need to avoid throwing the baby out with the bathwater by placing too much emphasis on disorder, uncertainty, congeries of contingencies, "the ephemeral, the emergent, ... the decentered and the heterogeneous" (Marcus 
and Saka 2006: 101), and thus giving short shrift to the non-contingent, to structured and systematic imperatives and constraints that are reproduced over time, and to generalization and explanation. "If pushed too far, if insisted on too literally - if it becomes anything more than an allusion-assemblage rapidly becomes a dead metaphor in one's work.... rigidifying into the thingness of final or stable states that besets the working terms of classical social theory" (ibid.: 106). A good way to guard against these dangers is to ground our descriptions and analyses in the kind of deep hanging out that has long been the hallmark of the ethnographic enterprise. Clearly, however, no combination of extant methodologies or conceptual/analytic terminologies can fully resolve all dilemmas associated with the ways we characterize the complexities we encounter in the field.

\section{REFERENCES}

Abu-Lughod, Lila. 2005. Dramas of Nationhood: The Politics of Television in Egypt. Chicago: University of Chicago Press.

Agrama, Hussein Ali. 2010a. Ethics, Tradition, Authority: Toward an Anthropology of the Fatwa. American Ethnologist 37, 1: 2-18.

Agrama, Hussein Ali. 2010b. Secularism, Sovereignty, Indeterminacy: Is Egypt a Secular or Religious State? Comparative Studies in Society and History 52, 3: 495-523.

Ahmad Hidayat Buang. 2007. Islamic Contracts in a Secular Court Setting? Lessons from Malaysia. Arab Law Quarterly 21: 317-40.

Ahmad, Imtiaz and Helmut Reifeld, eds. 2004. Lived Islam in South Asia: Adaptation, Accommodation, and Conflict. Delhi: Social Sciences Press.

Al-Attas, Syed Naguib. 1969. Preliminary Statement on a General Theory of the Islamization of the Malay-Indonesian Archipelago. Kuala Lumpur: Dewan Bahasa dan Pustaka.

Ali, Muhammad Mumtaz. 2010. The History and Philosophy of Islamization of Knowledge: A Preliminary Study of Pioneers' Thought. Kuala Lumpur: International Islamic University Malaysia.

Anderson, Ben, Matthew Kearnes, Colin McFarlane, and Dan Swanton. 2012. On Assemblages and Geography. Dialogues in Human Geography 2, 2: 171-89.

Appadurai, Arjun. 1986. Theory in Anthropology: Center and Periphery. Comparative Studies in Society and History 28, 2: 356-61.

Appadurai, Arjun. 1996. Modernity at Large: Cultural Dimensions of Globalization. Minneapolis: University of Minnesota Press.

Asad, Talal. 1986. The Idea of an Anthropology of Islam. Occasional Paper Series. Washington, D.C: Center for Contemporary Arab Studies, Georgetown University.

Asad, Talal. 1993. Genealogies of Religion: Discipline and Reasons of Power in Christianity and Islam. Baltimore: Johns Hopkins University Press.

Asad, Talal. 2003. Formations of the Secular: Christianity, Islam, Modernity. Stanford: Stanford University Press.

Bowen, John. 2003. Islam, Law, and Equality in Indonesia: An Anthropology of Public Reasoning. Cambridge: Cambridge University Press.

Bunnell, Timothy. 2004. Malaysia, Modernity, and the Multimedia Super Corridor: A Critical Geography of Intelligent Landscapes. Abingdon, Oxford: RoutledgeCurzon. 
Cannell, Fanella. 2010. The Anthropology of Secularism. Annual Review of Anthropology 39: 85-100.

Casanova, Jose. 1994. Public Religions in the Modern World. Chicago: University of Chicago Press.

Chandra Muzaffar. 1987. Islamic Resurgence in Malaysia. Kuala Lumpur: Fajar Bakti.

Clifford, James. 1986. Introduction: Partial Truths. In James Clifford and George Marcus, eds., Writing Culture: The Poetics and Politics of Culture. Berkeley: University of California Press.

Cohen, Jean. 1995. Interpreting the Notion of Civil Society. In Michael Walzer, ed., Toward a Global Civil Society. Providence: Berghahn.

Collier, Stephen J. and Aihwa Ong. 2005. Global Assemblages, Anthropological Problems. In Aihwa Ong and Stephen J. Collier, eds., Global Assemblages: Technology, Politics, and Ethics as Anthropological Problems. Malden, MA.: Blackwell.

Comaroff, John L. and Jean Comaroff. 2005. Law and Order in the Postcolony: An Introduction. In Jean Comaroff and John L. Comaroff, eds., Law and Disorder in the Postcolony. Chicago: University of Chicago Press.

Deleuze, Gilles and Felix Guattari. 1987. A Thousand Plateaus: Capitalism and Schizophrenia. Minneapolis: University of Minnesota Press.

Dupret, Baudouin. 2007. What Is Islamic Law? A Praxiological Answer and an Egyptian Case Study. Theory, Culture, and Society 24, 2: 79-100.

Fardon, Richard. 1990. Localizing Strategies. In Richard Fardon, ed., Localizing Strategies: Regional Traditions of Ethnographic Writing. Edinburgh: Scottish Academic Press.

Fealy, Greg. 2005. Islamization and Politics in Southeast Asia: The Contrasting Cases of Malaysia and Indonesia. In Nelly Lahoud and Anthony Johns, eds., Islam in World Politics. London: Routledge.

Fuller, Thomas. 2006. Malaysia's Secular Vision vs. 'Writing on the Wall.' New York Times, 28 Aug.

Geertz, Clifford. 2000. Available Light: Anthropological Reflections on Philosophical Topics. Princeton: Princeton University Press.

Government of Malaysia. 2010. Panduan Amalan 5S Sektor Awam [5S practice guide (book) for the civil service]. Putrajaya: MAMPU.

Hallaq, Wael. 2009. Shari'a: Theory, Practice, Transformations. Cambridge: Cambridge University Press.

Hamayotsu, Kikue. 2002. Islam and Nation Building in Southeast Asia: Malaysia and Indonesia in Comparative Perspective. Pacific Affairs 75, 3: 353-75.

Harding, Andrew. 1996. Law, Government, and the Constitution in Malaysia. Petaling Jaya: LexisNexis.

Harding, Andrew. 2012. The Constitution of Malaysia: A Contextual Analysis. Oxford: Hart Publishing.

Hefner, Robert W., ed. 2011. Shari 'a Politics: Islamic Law and Society in the Modern World. Bloomington: Indiana University Press.

Hooker, M. B. 1999. Qadi Jurisdiction in Contemporary Malaysia and Singapore. In Wu Min Aun, ed., Public Law in Contemporary Malaysia. Petaling Jaya: Longman.

Horowitz, Donald. 1994. The Qur'an and the Common Law: Islamic Law Reform and the Theory of Legal Change. American Journal of Comparative Law 2 \& 3: 233-93, 543-80.

Hussin Mutalib. 1993. Islam in Malaysia: From Revivalism to Islamic State? Singapore: Singapore University Press.

Jewell, Elizabeth and Frank Abate, eds. 2001. The New Oxford American Dictionary. Oxford: Oxford University Press. 
Juergensmeyer, Mark. 2003. Terror in the Mind of God: The Global Rise of Religious Violence. 3d ed. Berkeley: University of California Press.

Kamali, Mohammad Hashim. 2000. Islamic Law in Malaysia: Issues and Developments. Kuala Lumpur: Ilmiah Publishers.

Kepel, Gilles. 2002. Jihad: The Trail of Political Islam. Cambridge: Harvard University Press.

Kessler, Clive. 2008. Islam, the State and Desecularization in Malaysia: The Islamist Trajectory During the Badawi Years. In Norani Othman, Mavis Puthucheary, and Clive Kessler, Sharing the Nation: Faith, Difference, Power and the State 50 Years after Merdeka. Petaling Jaya: Strategic Information and Research Development Centre.

Knauft, Bruce. 1996. Genealogies for the Present in Cultural Anthropology. New York: Routledge.

Lee, Julian. 2010. Islamization and Activism in Malaysia. Singapore: Institute of Southeast Asian Studies.

Lévi-Strauss, Claude. 1966. The Savage Mind. Chicago: University of Chicago Press.

Liow, Joseph. 2009. Piety and Politics: Islamism in Contemporary Malaysia. Oxford: Oxford University Press.

Makdisi, George. 1985-1986. The Guilds of Law in Medieval Legal History: An Inquiry into the Origins of the Inns of Court. Cleveland State Law Review 34, 3: $3-18$.

Makdisi, John. 1999. The Islamic Origins of the Common Law. North Carolina Law Review 77: 1635-739.

Mamdani, Mahmood. 2004. Good Muslim, Bad Muslim: America, the Cold War, and the Roots of Terror. New York: Pantheon.

Marcus, George and Erkan Saka. 2006. Assemblage. Theory, Culture, and Society 23, 2-3: 101-6.

Marina Mahathir. 2010. Let Women Judges Do Their Jobs. The Star (Kuala Lumpur), 21 July.

Marsden, Magnus. 2005. Living Islam: Muslim Religious Experience in Pakistan's North-West Frontier. Cambridge: Cambridge University Press.

Maznah Mohamad. 2010. The Ascendance of Bureaucratic Islam and the Secularization of the Sharia in Malaysia. Pacific Affairs 83, 3: 505-24.

Mazzarella, William. 2006. Internet X-Ray: E-Governance, Transparency, and the Politics of Immediation in India. Public Culture 18, 3: 473-505.

Merry, Sally E. 1990. Getting Justice and Getting Even: Legal Consciousness among Working Class Americans. Chicago: University of Chicago Press.

Messick, Brinkley, 1993. The Calligraphic State: Textual Domination and History in a Muslim Society. Berkeley: University of California Press.

Moore, Sally Falk. 1978. Law as Process: An Anthropological Approach. London: Routledge and Kegan Paul.

Muhammad Abu Bakar. 1987. Penghayatan Sebuah Ideal: Suatu Tafsiran Tentang Islam Semasa [Appreciation of an ideal: an interpretation of contemporary Islam]. Kuala Lumpur: Dewan Bahasa dan Pustaka.

Muhammad Rais Abdul Karim and Nazariah Mohd Khalid. 2003. E-Government in Malaysia. Kuala Lumpur: Pelanduk Publications.

Nagata, Judith. 1984. The Reflowering of Malaysian Islam: Modern Religious Radicals and Their Roots. Vancouver: University of British Columbia Press.

Newfield, Christopher. 2007. Corporation. In Bruce Burgett and Glenn Hendler, eds., Keywords for American Cultural Studies. New York: New York University Press.

Nik Noriani Nik Badli Shah. 2008. Legislative Provisions and Judicial Mechanism for the Enforcement and Termination of the Islamic Marriage Contract in Malaysia. In 
Asifa Quraishi and Frank Vogel, eds., The Islamic Marriage Contract. Cambridge: Islamic Legal Studies Program, Harvard University Press.

Norani Othman. 2008. Religion, Citizen Rights and Gender Justice: Women, Islamization and the Shari'a in Malaysia since the 1980s. In Norani Othman, Mavis Puthucheary, and Clive Kessler, Sharing the Nation: Faith, Difference, Power and the State 50 Years after Merdeka. Petaling Jaya: Strategic Information and Research Development Centre.

Norani Othman, Mavis Puthucheary, and Clive Kessler. 2008. Sharing the Nation: Faith, Difference, Power and the State 50 Years after Merdeka. Petaling Jaya: Strategic Information and Research Development Centre.

Ong, Aihwa and Stephen J. Collier, eds. 2005. Global Assemblages: Technology, Politics, and Ethics as Anthropological Problems. Malden, MA.: Blackwell.

Otto, Jan Michiel, ed. 2010. Sharia Incorporated: A Comparative Overview of the Legal Systems of Twelve Muslim Countries in Past and Present. Leiden: Leiden University Press.

Peletz, Michael G. 1997. 'Ordinary Muslims' and Muslim Resurgents in Contemporary Malaysia: Notes on an Ambivalent Relationship. In Robert W. Hefner, ed., Islam in an Era of Nation States: Politics and Religious Renewal in Muslim Southeast Asia. Honolulu: University of Hawaii Press.

Peletz, Michael G. 2002. Islamic Modern: Religious Courts and Cultural Politics in Malaysia. Princeton: Princeton University Press.

Peletz, Michael G. 2005. Islam and the Cultural Politics of Legitimacy: Malaysia in the Aftermath of September 11. In Robert W. Hefner ed., Remaking Muslim Politics: Pluralism, Contestation, Democratization. Princeton: Princeton University Press.

Peletz, Michael G. 2011. Islamization in Malaysia: Piety and Consumption, Politics and Law. South East Asia Research 19, 1: 125-48.

Peletz, Michael G. n.d. Syariah Transformations. Book manuscript in preparation.

Rabinow, Paul. 1999. French DNA: Trouble in Purgatory. Chicago: University of Chicago Press.

Raihanah Abdullah, Patricia Martinez, and Wirdati Mohd. Radzi. 2010. Islam and Adat: Considering the Wife's Moral Contribution in the Division of Harta Sepencharian in Malaysia. Indonesia and the Malay World 38, 111: 161-80.

Ramizah Wan Muhammad. 2008. The Theory and Practice of Sulh (Mediation) in the Malaysian Shariah Courts. IIUM Law Journal 16, 1: 33-50.

Rittich, Kerry. 2001. Who's Afraid of the Critique of Adjudication? Tracing the Discourse of Law in Development. Cardozo Law Review 22, 3-4: 929-46.

Roff, William. 1967. The Origins of Malay Nationalism. Kuala Lumpur: University of Malaya Press.

Rudnyckyj, Daromir. 2010. Spiritual Economies: Islam, Globalization, and the Afterlife of Development. Ithaca: Cornell University Press.

Said, Edward. 1978. Orientalism. New York: Vintage.

Said, Edward. 1993. Culture and Imperialism. New York: Vintage.

Sa'odah binti Ahmad. 2010. The Effectiveness of Mediation and Sulh in Resolving Family Disputes: A Study of Parties' Satisfaction with Sulh in the State of Selangor. $\mathrm{PhD}$ diss., International Islamic University Malaysia.

Sassen, Saskia. 2008. Territory, Authority, Rights: From Medieval to Global Assemblages. Updated ed. Princeton: Princeton University Press.

Scott, David and Charles Hirschkind, eds. 2006. Powers of the Secular Modern: Talal Asad and His Interlocutors. Stanford: Stanford University Press.

Scott, James C. 1998. Seeing Like a State: How Certain Schemes to Improve the Human Condition Have Failed. New Haven: Yale University Press. 
Shaikh, Farzana. 2007. The Shariatization of Pakistani Nationalism. Occasional Paper no. 29, School of Social Science, Institute for Advanced Study. Princeton: Institute for Advanced Study.

Shamsul A. B. 2001. Shadow of Afghan War. Economic and Political Weekly, 22 Dec.: 4708-9.

Sharifah Zaleha Syed Hassan and Sven Cederroth. 1997. Managing Marital Disputes in Malaysia: Islamic Mediators and Conflict Resolution in the Syariah Courts. Richmond, Surrey: Curzon Press.

Shryock, Andrew. 2010. Introduction: Islam as an Object of Fear and Affection. In Andrew Shryock, ed., Islamophobia/Islamophilia: Beyond the Politics of Enemy and Friend. Bloomington: Indiana University Press.

Sloane-White, Patricia. 2011. Shariah Elites in Malaysia's Islamic Economy. Paper presented at the Association for Asian Studies Annual Meeting, Honolulu, Mar. 31-Apr. 3.

Soares, Benjamin and Filippo Osella. 2009. Islam, Politics, Anthropology. Journal of the Royal Anthropological Institute (N.S.) 15, S1: S1-S23.

Starrett, Gregory. 2010. The Varieties of Secular Experience. Comparative Studies in Society and History 52, 3: 626-51.

Strathern, Marilyn, ed. 2000. Audit Cultures: Anthropological Studies in Accountability, Ethics, and the Academy. London: Routledge.

Tan Beng Hui. 2012. Sexuality, Islam, and Politics in Malaysia: A Study on the Shifting Strategies of Regulation. PhD diss., National University of Singapore.

Weber, Max. 1925 [1968]. Wirtschaft und Gesellschaft. Grundriss der Verstehenden Soziolgie. Repr. as "Economy and Law (Sociology of Law)," in Guenther Roth and Claus Wittich, eds., Economy and Society: An Outline of Interpretive Sociology. 2 vols. Berkeley: University of California Press.

Whiting, Amanda. 2008. Desecularizing Malaysian Law? In Penelope (Pip) Nicholson and Sarah Biddulph, eds., Examining Practice, Interrogating Theory: Comparative Legal Studies in Asia. Leiden: Martinus Nijhoff.

Whiting, Amanda. 2010. Secularism, the Islamic State and the Malaysian Legal Profession. Asian Journal of Comparative Law 5, 1, article 10: 1-34.

Whiting, Amanda. 2011. Political Struggles and Practical Ethics: A History of Malaysian Lawyers and Lawyering. Paper presented at Workshop on Law and Society in Malaysia, University of Victoria, B.C., 14-16 July.

Abstract: This essay concerns transformations in the judicial apparatus involved in implementing Islamic law (syariah/shari' $a$ ) in Malaysia, a Muslim-majority nation in Southeast Asia. Three of my goals are to delineate some of the empirical complexities of the syariah judiciary's day-to-day operations and the mutually contradictory directions in which it is moving; to problematize the widely invoked trope of Islamization as a gloss for these phenomena; and to illustrate that this judiciary is profitably viewed as a global assemblage (Deleuze and Guattari 1987; Ong and Collier 2005). Another, more general, objective is to elucidate some of the ways that religion, law, and attendant phenomena are being bureaucratized, rationalized, corporatized, and otherwise transformed in an increasingly globalized world. 